\title{
Criminal Enforcement and the IRS
}

\author{
Robert L. Spatz \\ Staff Assistant to the Chief Counsel, Internal Revenue Service \\ B.B.A., 1950, College of the City of New York; LL.B., 1953, University of Michigan; \\ LL.M., 1959, Georgetown University
}

This nation is run, essentially, by income tax collections, and the Internal Revenue Service painstakingly enforces criminal sanctions on would-be evaders. Tax evasion strikes more directly at the sovereignty, and less directly at individual citizens, than other white-collar crimes. The raison d' etre for vigorous criminal tax enforcement is to deter tax evasion and to assure the taxpaying public that each individual taxpayer is held accountable for his fair share of the tax burden.

Trained investigators, known as special agents, play a key role in the enforcement program. Through their legwork and ingenuity, proof of tax liabilities is often pieced together from scattered third-party records and recollections. Criminal prosecution recommendations initiated by special agents at the completion of their investgations are screened at numerous levels before criminal charges are instituted. The results, in an average year, are over 90 per cent convictions in the roughly 1,000 prosecutions, with four out of five paying fines and one out of three going to jail. Criminal prosecution of tax evaders contributes in no small measure to the success of our self-assessment tax structure.

WV HY AND how tax COLLectors are in the criminal enforcement business is a subject that sometimes needs explanation, especially as it refers to the major source of federal revenues - the income tax.

\section{Income Taxes Run Nation}

There are-though some may tend to forget them-dozens of other federal taxes. For some-wagering, frearms, narcotics, alcohol and tobacco-the need for criminal sanctions is obvious on the face of things.

However, many may well wonder why criminal sanctions have any place at all with regard to the income tax, which reaches into every American home.
Let us first take a quick statistical look at fiscal year 1966 . Of the $\$ 128.8$ billion total federal collections, over $\$ 92$ billion came from income taxes. It is the American income taxpayer who finances his country-it is as sim. ple as that.

\section{1,000 Prosecutions}

If recent experience holds up, about one thousand of the almost seventy million Forms 1040 or 1040 A which were or should have been filed during fiscal 1966 will eventually produce criminal prosecutions for what can be labled as-at the risk of oversimplification-tax evasion. The thousand or so criminal tax defendants will come-from all walks of life and 
run the entire spectrum of income tax brackets. This will include professionals, businessmen, executives, farmers, and wage-earners. All but a few will have never before been in trouble with the law. To bring about their criminal prosecution, the Internal Revenue Service alone will expend over fifteen hundred man-years of effort by its specialized criminal investigators, plus over fifty attorney manyears-all this before the defendants enter the criminal courtroom.

How does all this hustle and bustle to enforce the criminal tax sanctions square with the common concepts of criminology?

\section{Tax Evasion-A Unique Crime}

In terms of the nature of the crime, income tax evasion-either by filing a false return or filing no return-is a very rare bird indeed. The tax evader leaves no identifiable victim bloodied or robbed in his wake. Persons who might not dream for a moment of hurting their fellow man may be tempted by the opportunity to underreport their tax liability when they take pen in hand on April 15 to fill out their Form 1040.

This does not refer to those parasitic tax crimes where someone is trying to make a living off the tax structure - such as the employer who fails to pay withheld trust fund taxes, the flyby-night who files multiple fraudulent refund returns in the hope that records of the district directors will not be cross-checked, the tax practitioner who pockets his client's money earmarked for payment of taxes, and the bribe giver or taker in an attempted tax fix.

It refers instead to the taxpayer who is doing what comes naturally by trying to hold on to as much of his money as he can and further-quite a lot further, I hasten to add-is willing to cross the line the law allows in order to do it. No other criminal sanction closely parallels tax evasion.

It becomes even more difficut to fit criminal tax sanctions on the framework of theoretical criminology when attention is turned from the nature of the crime to the purpose of imposing punishment. The three R"s of penology are utterly inoperative. Revenge by the injured sovereign? This retributive aspect-the discredited eyefor-an-eye notion-is handled separately by collecting the tax dollars which should have been paid in the first place. The second $\mathrm{R}$-removal of danger from society? Paradoxically, the evader is often a functioning cog in the local economy, so that putting him behind bars may in fact do damage to society. The third $\mathrm{R}-$ rehabilitation of the criminal as an individual? Recidivism is negligible among tax evaders - they usually are reformed the minute the revenue agent rings their doorbell.

Still, there is surely a purpose to punishment of convicted tax evaders. Four out of five pay fines; one out of three goes to jail.

The purpose is this: Vigorous criminal tax enforcement serves to deter the tens of thousands of taxpayers who might otherwise succumb to the temptation to try to cheat.

More importantly it serves to assure the tens of millions of other taxpayers, who willingly accept their taxpaying duties as the price of their civilization, that everyone else is held accountable for his fair share of the tax burden.

It is largely because of the criminal enforcement program that voluntary compliance with the tax laws has become an accepted way of life here. In countries where criminal tax sanc- 
tions do not exist or are winked at, the tax laws become nothing much more than scribblings in the statute book.

\section{Key Role of Special Agent}

The function of the executive branch in the government scheme of things is perhaps simpler than that of the legislative or the judicial branch. Congress must estimate the public will and welfare to determine and to define precisely what conduct should be declared criminal. The courts must make the soul-searching decision of exactly what punishment should be meted out to an individual convicted of tax evasion. Even so-as you may have surmised from the earlier figure of one thousand cases worked up every year by fifteen hundred investigators and fifty lawyers-the IRS takes most seriously the function of getting the right cases into the criminal courtrooms.

There are many possible sources for IRS cases-crumpled currency in a tin box dug up behind a garage, a report to the local police of a large jewel theft, a bookkeeper or a girl friend whose hasty dismissal a tax evader later repented in the leisure of a jail cell. Over ten thousand such information items are sifted by IRS criminal investigators every month. But it is the system itself-tax returns assigned for audit examination because of a patently questionable item or an educated sampling classification that generates most of the IRS criminal income-tax cases.

Whatever its origin, the tax cases with substantial, though as yet undeveloped, criminal potential will wind up in the capable hands of a special agent assigned to the Intelligence Division of one of the fifty-eight IRS district offices.
The special agent is the trained and dedicated professional whose shoulders carry the weight of the enforcement program. It is through his imaginativeness in detecting fraud, his leg work, his diligence in gathering the evidence from documentary records and third parties, and, most important of all, his sound and impartial judgment in making the initial recommendation to pursue the matter that the processing of a criminal tax prosecution is begun.

\section{Processing the Case}

The investigative phase of a criminal tax case may take several months or years. A special agent is in charge of the conduct of the investigation and method of procedure. $\mathrm{He}$ is usually assisted by a revenue agent, who attends to the audit, accounting, and tax features. Such teams of agents conducting joint investigations can, when the situation demands it, piece records of a taxpayer's transactions into almost a daily diary of his whereabouts and activities. For ingenuity and sheer tenacity IRS holds its tax gumshoes second to none.

The object of the investigation is to see whether the case satisfies Internal Revenue Service's standard of prosecution. The standard is two-fold. First, there must be available suffi. cient evidence to establish guilt beyond a reasonable doubt. Second, there must be a reasonable probability of securing a conviction. Over the years these dual tests have established a very finite framework for measuring the appropriateness of instituting prosecution.

Where, after his full-scale investigation, a special agent finds his case falling short of the standard of prosecution, he discusses it with his superi- 
ors. The decision to close such a case without prosecution is made by the chief of the Intelligence Division at the district level. That, for all practical purposes, is the probable end of the criminal aspects of the matter.

If, on the other hand, the special agent tentatively finds that his case satisfied the Revenue Service's standard of prosecution, the taxpayer is customarily afforded the opportunity of a formal conference at the district level. The purpose of the conference is to let the taxpayer offer whatever explanation he has. While the taxpayer is generally apprised of the alleged fraudulent features of the case, the IRS representative must sometimes speak guardedly so as not to invite fabricated defenses or endanger prospective witnesses. With this limitation in mind, the IRS representative does what he can to exchange relevant facts and ideas about the case.

On the heels of the formal conference, the special agent reaches his decision on whether to recommend prosecution. As indicated, where the decision is against prosecution the cáse can be closed with the concurrence of the district chief. However, if the special agent recommends prosecution, his final report, together with the exhibits in the case and memoranda of conferences, travel to one of the seven IRS regional offices.

Before it ever gets to trial, the recommended criminal income-tax case undergoes stringent and independent reviews by the assistant regional commissioner for Intelligence, the assistant regional counsel for Enforcement, the Criminal Section of the Tax Division of the Department of Justice, and the United States attorney. In essence, each of these successive levels of review generally gives the taxpayer another shot at stopping the case and the special agent another shot at moving it. The whole mechanism is intended to insure that the right cases-only those that are right, but all of those that are right-are criminally prosecuted.

That is not to say for a certainty that a conviction will be obtained in every one of the thousand or so criminal income-tax cases prosecuted annually. Through the years, though, this procedure has produced the rather remarkable record of convicting about 93 per cent of those prosecuted, a result that helps to keep the taxpaying public honest and content-and confident in the effective, evenhanded administration of the internal revenue laws. 